\title{
Allosterism of Nicotinic Acetylcholine Receptors: Therapeutic Potential for Neuroinflammation Underlying Brain Trauma and Degenerative Disorders
}

\author{
Swarup Mitra ${ }^{1, *,+}$, Shailesh N. Khatri ${ }^{2, \dagger}{ }^{,}$Malabika Maulik ${ }^{3, \dagger}{ }^{+}$, Abel Bult-Ito ${ }^{4}$ and \\ Marvin Schulte 5 \\ 1 Department of Pharmacology and Toxicology, The State University of New York at Buffalo, \\ Buffalo, NY 14203, USA \\ 2 Department of Cellular and Integrative Physiology, University of Texas Health Science Center at San Antonio, \\ San Antonio, TX 78229, USA; khatrisn@uthscsa.edu \\ 3 Department of Biochemistry and Neurology, Hunter James Kelly Research Institute, \\ The State University of New York at Buffalo, Buffalo, NY 14203, USA; malabika@buffalo.edu \\ 4 Department of Biology \& Wildlife, University of Alaska Fairbanks, Fairbanks, AK 99775, USA; \\ abultito@alaska.edu \\ 5 Department of Biomedical and Pharmaceutical Sciences, Idaho State University College of Pharmacy, \\ Pocatello, ID 83209, USA; schumarv@isu.edu \\ * Correspondence: swarupmi@buffalo.edu \\ + These authors contributed equally to this article.
}

Received: 30 June 2020; Accepted: 10 July 2020; Published: 12 July 2020

\begin{abstract}
Inflammation is a key physiological phenomenon that can be pervasive when dysregulated. Persistent chronic inflammation precedes several pathophysiological conditions forming one of the critical cellular homeostatic checkpoints. With a steady global surge in inflammatory diseases, it is imperative to delineate underlying mechanisms and design suitable drug molecules targeting the cellular partners that mediate and regulate inflammation. Nicotinic acetylcholine receptors have a confirmed role in influencing inflammatory pathways and have been a subject of scientific scrutiny underlying drug development in recent years. Drugs designed to target allosteric sites on the nicotinic acetylcholine receptors present a unique opportunity to unravel the role of the cholinergic system in regulating and restoring inflammatory homeostasis. Such a therapeutic approach holds promise in treating several inflammatory conditions and diseases with inflammation as an underlying pathology. Here, we briefly describe the potential of cholinergic allosterism and some allosteric modulators as a promising therapeutic option for the treatment of neuroinflammation.
\end{abstract}

Keywords: neuroinflammation; nicotinic acetylcholine receptors; allosteric modulators

\section{Introduction}

Inflammation is the body's defense mechanism that is pivotal for maintaining health status. Inflammation encompasses immune responses to noxious and harmful stimuli [1-5]. At the tissue level, inflammation involves the recruitment of plasma proteins, fluid and leukocytes into the damaged area resulting in vasodilation, a phenomenon characterized by a surge in blood flow, edema and increased vascular permeability [6]. Any damage signals are identified through transmembrane receptors such as Toll-like receptors (TLRs), the intracellular nucleotide-binding domain and leucine-rich-repeat-containing receptors (NLRs) [7-9]. Activation of these receptors often culminates in the potentiation of a critical transcription factor, the nuclear factor kappa-light-chain-enhancer of activated B cells (NF- $\mathrm{kB}$ ) that leads to translocation of NF- $\mathrm{kB}$ into the nucleus for promoting the 
transcription of target genes. Transcription and translation enable the expression of a set of these target genes that are mostly pro-inflammatory cytokines such as interleukins (ILs), tumor necrosis factor-alpha (TNF- $\alpha$ ) and others [10]. Inflammatory cytokines further coordinate with various cellular intermediates facilitating the recruitment of effector cells such as neutrophils and monocytes in the periphery and microglia and astrocytes in the central nervous system (CNS) [11]. These effector cells in turn undergo degranulation releasing reactive oxygen species (ROS), reactive nitric oxide species (RNS) and proteinases that promote the inflammatory process [11]. While infections are the primary factors underlying inflammation, injury or trauma and exposure to foreign matter can trigger inflammatory responses [12]. Emerging evidence shows that aging and environmental factors such as lifestyle, food habits and exercise can influence inflammation [13-17].

Inflammation is the underlying cause of several pathological conditions that impact more than 500 million patients across major pharmaceutical markets [2]. Despite significant strides in the development of therapeutic strategies against various inflammatory diseases, the major public health concern has been the link to a more persistent issue of chronic inflammation [2]. There is accruing evidence of the role of neuronal cholinergic mechanisms influencing neuroinflammatory cascades implicated in trauma and debilitating nervous system manifestations, such as clusters of neurodegenerative disorders, autoimmunity, and chronic nociception [4,18-21].

Historically, the cholinergic anti-inflammatory pathway emerged with the discovery of T-lymphocyte cytotoxicity via the muscarinic cholinergic system [22]. These claims were further corroborated in experiments demonstrating inhibition of T-cell differentiation and responses due to nicotine exposure $[23,24]$. Recent evidence points towards a $\mathrm{nAChR}$ mediated cholinergic regulation of inflammation in the CNS [2]. For example, the cholinergic anti-inflammatory pathway involving activation of nAChRs on the vagus nerve can inhibit cytokine release, thereby preventing their damaging effects, and has become an essential link between CNS and immunomodulation in response to immune challenges $[25,26]$. Recent studies have also shown that the cholinergic anti-inflammatory mechanisms extend beyond the aforementioned pathway involving discrete cascades in the CNS. $\alpha 7 \mathrm{nAChR}$ expression on primary dorsal root ganglion (DRG) neurons influences excitatory glutamatergic-signaling-mediating spinal analgesia [27-30]. Similarly, activation of $\alpha 7 \mathrm{nAChR}$ on astrocytes attenuates LPS-mediated upregulation of inflammatory cytokines through inhibition of the ubiquitous NF-kB inflammatory pathway [31]. Additionally, $\alpha 7$ involves phosphorylation of STAT3, a mediator of an anti-apoptotic cascade under inflammatory challenge conditions [32].

Pharmacological targeting of nAChRs has therefore gained traction in recent years to address its role in inflammation. Despite successful drug design, the molecules designed to target primary active (orthosteric) sites often have limitations, as these sites are highly conserved [33]. Thus, drugs designed for this site often end up having overlapping specificity. On the contrary, drugs targeted to the secondary (allosteric) binding sites carry greater pharmacological potential [33]. This review emphasizes the potential of cholinergic allosterism as an emerging approach to drug design for the treatment of chronic neuroinflammation. We predominantly focus on traumatic brain injury (TBI) and major neurodegenerative disorders, Alzheimer's (AD), Parkinson's (PD) and Multiple sclerosis (MS) in which inflammation forms a significant pathological basis [34]. We highlight the role of nAChRs in influencing the neuroinflammatory mechanisms underlying these pathophysiologies and how allosteric targeting of some of the nAChRs subtypes can formulate a potential therapeutic strategy for successfully treating these disorders.

\section{Nicotinic Acetylcholine Receptors and Allosterism}

The nAChRs are members of the Cys-loop superfamily of receptors that include GABAA, glycine and serotonin receptors [35-37]. nAChRs are large pentameric membrane-bound proteins of a molecular mass of $290 \mathrm{KD}$. Each receptor is formed by combinations of five identical (i.e., homomeric) or different (i.e., heteromeric) subunits. The subunits that contribute to nAChRs are $\alpha$ $(\alpha 2-\alpha 9)$ and $\beta(\beta 2-\beta 4)$ [35]. The diversity of subunit configuration and assembly results in a myriad 
of receptor subtypes with varied sensitivity to ligands. Adding to the complexity and variability of nAChRs, each heteromeric receptor may potentially exhibit different stoichiometry based on the ratio of $\alpha: \beta$ subunits present and varied sensitivities to endogenous ligand (acetylcholine, ACh) [38]. One of the widely studied nAChRs and their stoichiometries are the $\alpha 4 \beta 2$ receptors, which comprise of high sensitive (HS) $(\alpha 4) 2(\beta 2) 3$ and low sensitive (LS) $(\alpha 4) 3(\beta 2) 2$ receptor organization $[39,40]$. Such stoichiometric variation coupled with context-dependent intrinsic biophysical properties and participation of other $\alpha$ or $\beta$ subunits imparts unique heterogeneity in the physiological functionality of the nAChRs [38]. The predominant nAChR subtypes expressed in the CNS comprise of $\alpha 4$ and $\beta 2$ subunits [36,41]. Additionally, $\alpha 6 \beta 2$ and $\alpha 7$ subtypes are abundantly found in the CNS, while $\alpha 6 \beta 4$ exhibit limited distribution [42]. Post-synaptically, they facilitate fast cholinergic neurotransmission, and pre-synaptically they modulate the release of other neurotransmitters and, therefore, play diverse roles ranging from cognition to modulation of neurotransmitters, and neuroprotection [43].

$\mathrm{nAChRs}$ are fast desensitizing ligand-gated ion channels that are activated by ligands binding at the orthosteric site [44-46]. Most therapeutic ligands are targeted towards the orthosteric site where they alter synaptic neurotransmission and receptor expression profiles. Thus, prolonged activation of $\mathrm{nAChRs}$ at the orthosteric site often results in tolerance or insensitivity to the drug [47], suggesting that suboptimal or non-orthosteric activation may be beneficial. Despite the layers of heterogeneity in nAChRs exhibited by its subunits, stoichiometries and biophysical properties, the ACh binding site, where all agonist, partial agonist or antagonist bind, is highly conserved [48]. This posits a limitation in the development of a clinically usable new ligand with adequate specificity across diseases in which $\mathrm{nAChRs}$ are involved, including inflammation. Hence, besides tolerance/insensitivity, ligands developed for orthosteric sites lack specificity and may lead to potential side effects [49]. However, allosteric ligands present a great potential, as they act through binding to a non-orthosteric site and activate nAChRs only in the presence of endogenous ligands such as ACh [49].

By definition, allosteric ligands bind to non-orthosteric sites and may possess intrinsic activity or may be ineffective by themselves, i.e., possess no intrinsic activity. The allosteric ligands that possess no intrinsic activity are also referred to as allosteric modulators (AMs) $[33,49,50]$. The number of allosteric sites present, and their structural diversity exclusively depends on the subunit type and the subunits that assemble structurally to form a functional receptor [51-56]. This allows diversity on the allosteric site, as well as potential tunability of nAChRs to produce greater specificity. Allosteric modulators/ligands can either enhance or reduce the $\mathrm{nAChR}$ responses induced by ACh [47]. Ligands that enhance the ACh responses are positive allosteric modulators (PAMs), whereas those that reduce ACh responses are known as negative allosteric modulators (NAMs) [47]. Allosteric modulators may impart their effects on ACh-induced responses by inducing a change in ACh potency or by altering efficacy and/or receptor opening probability without affecting baseline neurotransmission [47,57].

Different types of PAMs targeting $\alpha 7 \mathrm{nAChRs}$ are studied and classified as type I and II, based on the mechanism by which they modulate the receptors [58]. The type I PAM increases Ach-induced current amplitudes, potentially through increasing ACh potency and efficacy, with minimal effect on receptor kinetics. Type II PAMs, however, work by altering receptor kinetics, specifically by slowing the desensitization and deactivation, leading to prolonged activation of receptors [59]. Another class of PAMs exists that exhibit intrinsic activity, i.e., they can directly activate the receptors. PAMs that potentiate orthosteric agonist-induced currents and possess intrinsic activity are called agonist-PAMs or Ago-PAMs [60]. For detailed accounts of allosteric modulation, underlying mechanism and receptor states please refer to these reviews [61-63].

\section{Neuroinflammation and Potential of Cholinergic Allosterism}

In the brain, chronic inflammation is a persistent cellular anomaly that is associated with several neurological disorders [64]. Despite having divergence in inflammatory inducers specific to each disease, there is convergence in mechanisms underlying amplification of inflammatory processes [64]. Under optimal physiological conditions, microglia, the resident immune cells of the brain, exhibit a 
deactivated phenotype [65]. Alteration to a more activated inflammatory phenotype occurs in response to an immune stimulus [64]. A sustained stimulus disrupts the homeostatic balance in the inflammatory mechanisms inflicting a chain of events that often results in neurotoxic challenges involving ROS, RNS and pro-inflammatory cytokines manifesting into cytokine-mediated diseases [66,67]. Additionally, the neurotoxic events often cause reactive astrocytosis, increased vascular permeability, extravasation of proteins, blood-brain barrier alterations and axonal demyelination that aid in amplifying the underlying disease states [64]. Neuroinflammation forms an integral aspect of some of the most devastating neurological disorders that will be discussed in the following sections.

\subsection{Alzheimer's Disease (AD)}

$\mathrm{AD}$ is an age-related devastating neurodegenerative condition that progressively impairs cognition, affective functionality and social well-being [68]. At the pathological level, AD is characterized by $\beta$-amyloid plaques and neurofibrillary tangles and symptomatically often involves dementia, speech impairments and disorientation, eventually leading to loss of self-care and death [68-70]. Epidemiological observations and postmortem analysis have corroborated inflammatory dysregulation as a major contributing factor to the disease state [71,72]. Decades of research have implicated various inflammatory mediators in the onset and progression of a persistent neuro-inflammatory cycle that initiates and exacerbates the AD pathology [73-82]. Age-related oxidative imbalance that might be further influenced through environmental triggers is often the starting point that leads to ROS and RNS production through the concerted action of several inflammatory cytokines such as IL-1, IL-6, TNF- $\alpha$ and oxidative enzymes such as NADH oxidase and nitric oxide synthase [69,73-85]. The disproportionate ratio of the oxidative species can further lead to exaggerated cytokine responses. Such incremental cytokine production over a period of time can synergistically produce distress signals to the astrocytes and microglia, which express more cytokines producing an inflammatory hotspot [86]. These anomalous mechanisms coupled with a genetic predisposition for AD disrupt the overall cellular homeostatic balance towards a more pathological phenotype [87].

Cholinergic hypofunction typical of $\mathrm{AD}$ is an established phenomenon and loss of cholinergic pathways is an important contributor to dementia pertaining to attention, spatial and episodic domains $[88,89]$. Using acetylcholinesterase (AChE) inhibitors has, therefore, proven to be one of the most viable therapeutic options for symptomatic improvement [90]. There is evidence on the role of nAChRs in mediating inflammatory mechanisms underlying AD [91]. The interactions of the cholinergic system and a ubiquitous neurotrophin, nerve growth factor (NGF) in the manifestation of $\mathrm{AD}$ is a well-known phenomenon [92-96]. The cholinergic neurons of the basal nucleus of Meynert are deprived of trophic support due to dysregulated retrograde transport of NGF. Such disruption of NGF transport mechanisms in conjunction with cholinergic transmission exacerbates $\beta$-amyloid mediated toxicity in cholinergic neurons [97-100]. Since NGF has an established role in influencing inflammatory mechanisms [101], the intertwining role of NGF and cholinergic transmission at the level of receptor pharmacology warrants investigation. Further, postmortem analysis has demonstrated up to a $50 \%$ reduction in $\alpha 4 \beta 2 \mathrm{nAChRs}$ in the brain of AD patients [102], early in pathogenesis [103]. Additionally, both $\alpha 4$ and $\alpha 7$ subunits exhibit reduced expression in autopsy samples of the human cerebral cortex of AD patients [104-106]. With such extensive involvement of the cholinergic system in $\mathrm{AD}$ pathophysiology, one of the pressing questions is regarding the pharmacological modulation of $n A C h R s$ in influencing the disease state. In-vitro administration of nicotinic agonists in PC12 cells and rat cortical neurons inhibits $\beta$-amyloid associated toxicity while chronic nicotine administration in a transgenic $\mathrm{AD}$ mouse model attenuates $\beta$-amyloidosis and neurite atrophy by decreasing astrogliosis, a phenomenon typical of neuroinflammation [107-110]. The neuroprotective mechanism against $\beta$-amyloid toxicity is mediated through the $\alpha 7$-Janus kinase 2 (JAK2) pathway that involves the association of JAK2 with $\alpha 7 \mathrm{nAChR}$ subsequently activating phosphoinositide 3-kinase (PI3K) and protein kinase B (Akt) phosphorylation $[107,111,112]$. These findings have further been supported through findings in the AD mouse model implicating an $\alpha 7$-regulated pro-survival cascade involving 
mitogen activated protein kinase (MAPK), Bcl2 and NF- $\mathrm{BB}$. Blocking $\alpha 7$ receptors by specific antibodies causes neuroinflammation leading to Alzheimer's-like symptoms in rodents [91]. Additionally, the interactions of $\alpha 7 \mathrm{nAChRs}$ with $\beta$-amyloid have been well documented [113-115] implicating nAChRs and their pharmacological targeting as a critical avenue for therapeutic value in AD.

\subsection{Parkinson's Disease (PD)}

PD is a neurodegenerative disorder that progressively worsens with age [116]. Aggregation of $\alpha$-synuclein in cells of the substantia nigra in the brain and loss of dopaminergic neurons are the major pathological hallmarks [117-119]. PD is associated with impaired movement and reduced cognitive function $[120,121]$. The etiology of PD can be attributed to a combination of environmental and genetic factors [122-125]. Nicotinic neuroprotection in PD is evidenced through several experimental studies [126-129]. Nicotine protects against nigrostriatal lesions caused by 6-hydroxydopamine (6-OHDA) and 1-methyl-4-phenyl-1,2,3,6-tetrahydropyridine (MPTP) insults that recapitulate PD-like pathology [127,130-134]. 6-OHDA and MPTP produce neuronal atrophy through oxidative stress and exacerbated microglial activation mechanisms, which are essential for neuroinflammation [135]. Therefore, the role of $n A C h R s$ becomes critical in PD. The striatal nAChR subtypes (including $\alpha 4 \beta 2$ ) are also reduced due to nigrostriatal damage $[136,137]$. Further, post-mortem brain analysis of PD patients has revealed neuroinflammation as a contributing factor in $\alpha$-synuclein mediated neurotoxicity and PD patients display higher striatal levels of TGF- $\beta$, IL-1 $\beta$, IL-6, IFN- $\gamma$ and IL-1 [138-142]. Pharmacological targeting of both $\alpha 4 \beta 2$ and $\alpha 7$ receptors $[132,133,143]$ has shown neuroprotective effects in 6-OHDA-lesioned rats by partially modulating Parkinson's pathology, while $\alpha 4$ knockout does not show nicotine-mediated neuroprotection of dopaminergic neurons [144] emphasizing the importance of $\mathrm{nAChRs}$ in modulating pathological endpoints. Moreover, nicotine administered both before and after 6-OHDA insult was shown to be more effective against partial, but not complete dopaminergic lesions in the substantia nigra [130].

In addition to the conventional nAChR subtypes, there is emerging evidence of the importance of $\alpha 6$ and $\alpha 5$ subunits in regulating dopaminergic transmission $[145,146]$. Recent research implicates cellular calcium imbalance $[147,148]$ as a probable mechanism underlying $\mathrm{nAChR}$ regulation. nAChR-mediated calcium alterations lead to signal transduction involving PI3K and or JAK2/STAT3 signaling that eventually alters inflammatory endpoints and pro-survival cascades [148].

\subsection{Multiple Sclerosis (MS)}

MS is an inflammatory autoimmune disorder that is characterized by chronic inflammatory demyelination and axonal degeneration in the CNS [149]. This process occurs both in white matter and grey matter [150], which results in disruption of axonal transmission causing motor and sensory impairments [149]. Though the precise molecular events that lead to MS are unknown, inflammatory anomalies, a key phenomenon in the disease pathology, result in the breakdown of the blood-brain barrier vascular endothelium affecting myelin and oligodendrocytes [151,152]. Further, activation of lymphocytes, macrophages, dendritic cells, and microglia are observed at the onset of the disease $[153,154]$. A cholinergic role in neuroinflammation and MS is evident by the presence of acetylcholinesterase (AChE), an enzyme regulating ACh turnover, and its variants in neurons, blood cells, white matter, glia and lymphocytes [155-157]. Nicotine has been shown to inhibit experimental MS in rodents [158,159], suggesting immune function could be manipulated by targeting cholinergic pathways of immune cells by specific ligands, potentially AMs [160,161]. The most promising target thus far has been $\alpha 7 \mathrm{nAChR}$. The immune cells expressing $\alpha 7$ also express a protein called RIC-3 (resistance to inhibitors of cholinesterase 3 ) that aids in the surface expression of $\alpha 7 \mathrm{nAChR}$, influencing the disease state and are being considered as cholinergic targets of MS [162]. Additionally, neuroinflammation induced by lipopolysaccharide (LPS) insult in rats was inhibited through activation of $\alpha 7 \mathrm{nAChR}$ [163]. Inhibition of AChE is shown to curb inflammation by reducing lymphocyte proliferation and secretion of proinflammatory cytokines such as TNF- $\alpha$, 
IL-B and IL-6 in mice, indicating that targeting AChE may provide a positive outcome in the treatment of MS [149,164,165]. In the experimental autoimmune encephalomyelitis (EAE) mouse model of human MS, choline acetyltransferase (ChAT) expression, an indicator for ACh presence/synthesis, in natural Killer (NK) cells is observed. ChAT positive cells promote migration of NK cells into the CNS, ameliorating the disease severity $[166,167]$. It was found that mature NK cells expressing ChAT were able to repress EAE induction and had a greater capacity to delay disease onset and decrease symptom severity compared to NK cells devoid of ChAT $[168,169]$. Using an agonist of $\alpha 7 \mathrm{nAChRs}$ in EAE showed that the activation of $\alpha 7$ is necessary for the suppression of EAE clinical severity [170]. These findings support other accounts that higher serum levels of ACh are observed in MS patients receiving treatments [171,172]. Hence there is substantial evidence suggesting that increasing cholinergic signaling in MS patients may ameliorate their symptoms.

\subsection{Traumatic Brain Injury (TBI)}

TBI is due to injury from an external force and is a major human health concern that impacts people of all ages [173]. TBI poses a major socioeconomic burden with devastating long-term consequences [174]. External trauma results in leakage of the blood-brain barrier (BBB) that initiates the infiltration of inflammatory cells [175-177]. Preclinical studies have established that TBI dysregulates cholinergic mechanisms that are characterized by reductions in choline uptake, choline acetyltransferase activity and vesicular acetylcholine transporter activity [178-181]. At the receptor level, $\alpha 7$ receptor expression is attenuated by $50 \%$ [181]. These results have further been substantiated in human TBI studies [182-184]. More recent evidence is emerging on the role of nAChRs in modulating the inflammatory profile in TBI $[185,186]$. nAChR $\alpha 7$ null mice exhibit potentiated levels of TNF- $\alpha$ and IL- $\beta$ levels concomitant with a leaky BBB [156]. Whereas systemic administration of the nAChR $\alpha 7$ agonist PNU-282987 or the positive allosteric modulator PNU-120596 significantly attenuates TBI-triggered BBB compromise [156]. Further, quantitative autoradiography in TBI rats shows reduced $\alpha 7, \alpha 4$ and $\alpha 3$ binding in various brain regions and activating $\alpha 7$ results in a dampened inflammatory cytokine response $[187,188]$.

\section{Potential Allosteric Modulators as Therapeutics}

The development of AMs-based therapeutics targeting nAChRs remains challenging because of the heterogeneous and unique role of $\mathrm{nAChRs}$ in promoting neuroinflammation. However, several selective and non-selective AMs are available that can be repurposed as lead molecules to design promising candidates. We believe the greater strategy would be to employ deconstruction-reconstruction (D-R) approaches to the existing AMs, generate analogs and screen them for positive or negative allosteric modulation. Briefly, the D-R approach involves fragmentation of known ligands, where each fragment can serve as a key pharmacophore. Upon analysis and optimization, a suitable fragment that enables orthosteric ligand to stabilize active (open) receptor conformation is selected for reconstruction. Reconstruction is relatively challenging as it not only calls for merging, linking or growing fragments to develop drugs but also to adhere to classical guidelines for maintaining physicochemical properties such as LogP, topological polar surface area, molecular weight, etc. [189-191].

Desformylfulstrabromide ( $\mathrm{dFBr})$ is a PAM of neuronal $\alpha 4 \beta 2$ receptors, first extracted from the bryozoan Flustra foliacea [192]. dFBr exhibits a bell-shaped dose-response curve where it enhances ACh induced currents in $\alpha 4 \beta 2$ receptors at lower concentrations and inhibits them at higher concentrations [193]. At potentiating concentrations, $\mathrm{dFBr}$ is thought to rescue the receptor from the desensitizing state leading to greater potentiation [193]. dFBr does not show any potentiation of nAChRs containing $\alpha 3$ or $\alpha 7$ receptors [52,194]. In rats and mice, dFBr was shown to reduce intravenous nicotine self-administration without supporting self-administration behavior [195] and compulsive-like behavior [196,197], respectively. In mouse models of neuropathic pain, dFBr potentiates antiallodynic responses of nicotine [198], suggesting that $\mathrm{dFBr}$ can be used in combination with an agonist or partial agonist to enhance or maintain cholinergic tone. In the same study, dFBr failed to affect 
allodynia when solely injected on its own. In vivo and in vitro activation of $\alpha 4 \beta 2 \mathrm{nAChRs}$ on mouse inflammatory macrophages by agonists are shown to alleviate inflammation-mediated neuropathic pain [199]. Also, $\mathrm{dFBr}$ has been found to relieve $\beta$-amyloid peptide (A $\beta 1-42)$ mediated loss of $\alpha 4 \beta 2$ function in oocytes [200]. This further solidifies the role of $\alpha 4 \beta 2$ and the potential of $\mathrm{dFBr}$ as a lead therapeutic molecule.

NS9283 is a selective PAM of $\alpha 4 \beta 2$ receptors, developed at Neurosearch Inc. Specifically, it enhances ACh-induced currents of LS stoichiometry [55,56]. Analogs of NS9283 have been shown to be selective for other variants of the receptor, including $\alpha 4 \alpha 5 \beta 2$ [201]. Given the potential involvement of $\alpha 5$-containing receptors in neuroinflammation, these analogs of NS9283 may be valuable leads in developing selective and therapeutically useful anti-inflammatory AMs.

NS206 is a PAM selective for the $\alpha 4$ subunit [56] and it potentiates both the LS and HS stoichiometry. NS206 has similar potencies for $\alpha 4 \beta 2$ and $\alpha 4 \beta 4$ receptors but does not potentiate $\alpha 3 \beta 4$ or $\alpha 7$ receptors. The ability to potentiate HS $\alpha 4 \beta 2$ receptors is of particular advantage as they are thought to be involved in neurological disorders including neuroinflammation [56,202]. Unlike NS9283, NS206 enhances ACh efficacy rather than potency [203]. Both NS206 and NS9283 are selective for the $\alpha 4$ subunit, however, their binding sites have been mapped to different domains of the same subunit. When co-applied, their effects are additive [203].

Galantamine is a plant-based alkaloid from the amaryllis family [204]. It was first identified as an anti-acetylcholinesterase and later found to be a type I PAM for nAChRs [205,206]. Galantamine has been used clinically for Alzheimer's disease [207] and has also been explored as a potential therapeutic option for Autism [208]. Evidence suggests that galantamine is a PAM for human $\alpha 4 \beta 2$ and $\alpha 7$ receptors. Galantamine was shown to enhance ACh responses by $22 \%$ in $\alpha 7$ receptors at lower concentrations and reduce them at higher concentrations, producing a bell-shaped dose-response curve [209], a typical feature of most PAMs. As galantamine exhibits both PAM and NAM activity at different concentrations, it is possible to construct analogs possessing either PAM or NAM activity without acetylcholinesterase activity [210]. This notion is further substantiated by a recent finding that galantamine's [211] and a selective agonist's [212] anti-inflammatory effects are mediated by $\alpha 7$ receptors. Similarly, other acetylcholinesterase inhibitors such as physostigmine [213] can also be explored for cholinergic anti-inflammatory activity. A recent conflicting study suggested that galantamine is not a PAM of either $\alpha 4 \beta 2$ or $\alpha 7$ receptors expressed in Xenopus oocytes and HEK 293 cells [209]. Nevertheless, galantamine does provide a substrate for designing a specific PAM or NAM that could enable the optimal functioning of the nAChRs for recovering aberrant inflammatory activation. Furthermore, the PNU series of PAMs (e.g., PNU-120596) and Ago-PAM (GAT-107) for $\alpha 7$ receptors are shown to reduce nociceptive behavior, neuropathic pain and thermal hyperalgesia [214-217] and could be potential leads for developing AMs in treating neuroinflammation.

Levamisole is an effective anthelmintic that binds to nematode muscle nAChRs [218]. Due to side effects like severe dermatological lesions, its use in humans is curbed, however, they are still used in veterinary medicine [218-220]. In humans, levamisole has also been used as an adjuvant in colon cancer therapy [221] and is a common intentional contaminant of cocaine [222,223]. Levamisole was identified as a PAM of $\alpha 3$ containing nAChRs. It potentiates ACh-induced responses at $\alpha 3 \beta 2$ receptors at lower concentrations and inhibits them at higher concentrations [224]. It also acts as a partial agonist of $\alpha 3 \beta 4$ receptors at very high concentration. Levamisole poses several serious side effects including elicitation of inflammatory diseases [225], however, they are not explicitly attributed to its PAM activity on nAChRs. It is possible to design receptor subtype-specific analogs of levamisole while retaining its PAM activity and minimizing observed side effects. Further thorough research is warranted before levamisole can be developed as an anti-inflammatory therapeutic agent.

Another promising compound, HEPES, is a commonly used buffering agent, that is shown to selectively potentiate HS $\alpha 4 \beta 2$ while slightly inhibiting LS $\alpha 4 \beta 2$ receptors [39]. Likewise, several piperidines (e.g., CMPI) and their analogs have been identified as potent, as well as selective $\alpha 4 \beta 2$ nAChR PAMs $[53,54]$. 


\section{Conclusions}

Appropriate drug candidates and cellular targets to combat dysregulation of fundamental inflammatory pathways underlying numerous inflammatory driven neurodegenerative conditions are currently lacking. With chronic inflammation being implicated in several devastating diseases, such as $\mathrm{AD}, \mathrm{PD}, \mathrm{MS}$ and TBI, a thorough screening of some of the cellular mediators that lie at the crossroads of inflammation needs to occur. Mounting evidence shows that cholinergic mechanisms significantly overlap with inflammatory cascades and carry the potential to modulate the molecular mechanisms and functional outcomes of inflammation. Current research on the neuro- immunomodulatory role of nAChRs has been minimal. Further, most AMs that are synthetically designed in the laboratories are often not pursued extensively with regards to their therapeutic potential. One of the primary reasons for this shortcoming is due to the lack of understanding of the structure-function relationship. For example, multiple allosteric binding sites have been proposed for $\mathrm{dfBr}$ that can presumably result in varied functional outcomes at the cellular level. This has however not been explored with respect to other AMs of nAChRs discussed here in the review. Thus, there remains a great potential in understanding how characterizing individual allosteric binding of these drug molecules can provide a resolution on the functional outputs augmenting their therapeutic potential. As this review highlights, nAChRs carry the prospect of being candidate targets to restore inflammatory homeostasis through allosteric regulation (Figure 1). This could potentially fill a gap in the therapeutic targeting of one of the key mediators of inflammatory conditions, thereby addressing a pressing public health issue of the current times.
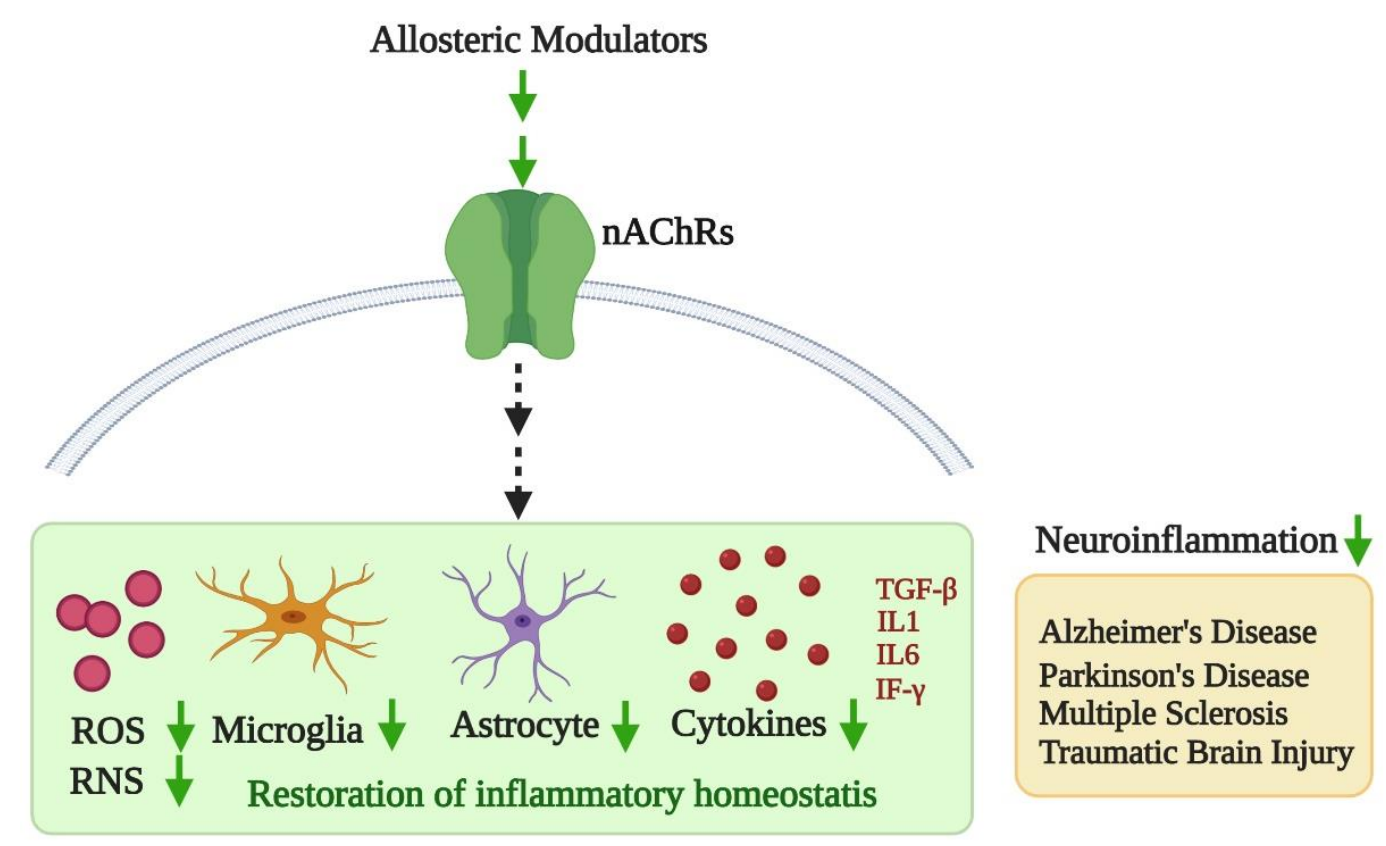

Figure 1. Proposed model of allosteric modulation in inflammation: Allosteric modulators can potentially restore cholinergic transmission in the cells by binding to neuronal acetylcholine receptors (nAChRs). This can attenuate the exacerbated expression of predominant inflammatory mediators such as reactive oxygen species (ROS), reactive nitric oxide species (RNS), astrocytes, microglia and cytokines such as TGF- $\beta$ (Transforming growth factor-beta), interleukin 1 (IL-1), interleukin 6 (IL-6) and interferon-gamma (IF- $\gamma)$.

Author Contributions: S.M., S.N.K. and M.M. conceptualized and wrote the manuscript with inputs from A.B.-I. and M.S. All authors have read and agreed to the published version of the manuscript.

Funding: The funding for publication cost of this article is provided by the Department of Biomedical and Pharmaceutical Sciences, Idaho State University College of Pharmacy. 
Conflicts of Interest: The authors declare no conflict of interest. The funders had no role in the design of the study; in the collection, analyses, or interpretation of data; in the writing of the manuscript, or in the decision to publish the results.

\section{References}

1. Lennertz, R.C.; Kossyreva, E.A.; Smith, A.K.; Stucky, C.L. TRPA1 mediates mechanical sensitization in nociceptors during inflammation. PLoS ONE 2012, 7, e43597. [CrossRef] [PubMed]

2. Bencherif, M. Neuronal nicotinic receptors as novel targets for inflammation and neuroprotection: Mechanistic considerations and clinical relevance. Acta Pharmacol. Sin. 2009, 30, 702-714. [CrossRef] [PubMed]

3. Bencherif, M.; Lovette, M.E.; Fowler, K.W.; Arrington, S.; Reeves, L.; Caldwell, W.S.; Lippiello, P.M. RJR-2403: A nicotinic agonist with CNS selectivity I. In vitro characterization. J. Pharmacol. Exp. Ther. 1996, 279, 1413-1421. [PubMed]

4. Weiner, H.L.; Selkoe, D.J. Inflammation and therapeutic vaccination in CNS diseases. Nature 2002, 420, 879-884. [CrossRef] [PubMed]

5. Vigano, P.; Rabellotti, E.; Pagliardini, L.; Somigliana, E.; Candiani, M.; Vercellini, P. Progesterone Resistance, Aromatase, and Inflammation: The Important Relationships Between Hormones and Inflammation. Curr. Obstet. Gynecol. Rep. 2012, 1, 146-152. [CrossRef]

6. Ashley, N.T.; Weil, Z.M.; Nelson, R.J. Inflammation: Mechanisms, Costs, and Natural Variation. Annu. Rev. Ecol. Evol. Syst. 2012, 43, 385-406. [CrossRef]

7. Roach, J.C.; Glusman, G.; Rowen, L.; Kaur, A.; Purcell, M.K.; Smith, K.D.; Hood, L.E.; Aderem, A. The evolution of vertebrate Toll-like receptors. Proc. Natl. Acad. Sci. USA 2005, 102, 9577-9582. [CrossRef]

8. Gao, W.; Xiong, Y.; Li, Q.; Yang, H. Inhibition of Toll-Like Receptor Signaling as a Promising Therapy for Inflammatory Diseases: A Journey from Molecular to Nano Therapeutics. Front. Physiol. 2017, 8. [CrossRef]

9. Bell, J.K.; Mullen, G.E.D.; Leifer, C.A.; Mazzoni, A.; Davies, D.R.; Segal, D.M. Leucine-rich repeats and pathogen recognition in Toll-like receptors. Trends Immunol. 2003, 24, 528-533. [CrossRef]

10. Ghosh, S.; May, M.J.; Kopp, E.B. NF-kappa B and Rel proteins: Evolutionarily conserved mediators of immune responses. Annu. Rev. Immunol. 1998, 16, 225-260. [CrossRef]

11. Nathan, C. Points of control in inflammation. Nature 2002, 420, 846-852. [CrossRef] [PubMed]

12. Medzhitov, R. Origin and physiological roles of inflammation. Nature 2008, 454, 428-435. [CrossRef] [PubMed]

13. De Vries, M.A.; Klop, B.; Janssen, H.W.; Njo, T.L.; Westerman, E.M.; Castro Cabezas, M. Postprandial inflammation: Targeting glucose and lipids. Adv. Exp. Med. Biol. 2014, 824, 161-170. [CrossRef] [PubMed]

14. Herieka, M.; Erridge, C. High-fat meal induced postprandial inflammation. Mol. Nutr. Food Res. 2014, 58, 136-146. [CrossRef] [PubMed]

15. Choi, J.; Joseph, L.; Pilote, L. Obesity and C-reactive protein in various populations: A systematic review and meta-analysis. Obes. Rev. 2013, 14, 232-244. [CrossRef] [PubMed]

16. You, T.; Arsenis, N.C.; Disanzo, B.L.; Lamonte, M.J. Effects of exercise training on chronic inflammation in obesity: Current evidence and potential mechanisms. Sports Med. 2013, 43, 243-256. [CrossRef]

17. Gjevestad, G.O.; Holven, K.B.; Ulven, S.M. Effects of Exercise on Gene Expression of Inflammatory Markers in Human Peripheral Blood Cells: A Systematic Review. Curr. Cardiovasc. Risk Rep. 2015, 9, 34. [CrossRef]

18. Davidson, A.; Diamond, B. Autoimmune diseases. N. Engl. J. Med. 2001, 345, 340-350. [CrossRef]

19. Franklin, R.J.; Ffrench-Constant, C.; Edgar, J.M.; Smith, K.J. Neuroprotection and repair in multiple sclerosis. Nat. Rev. Neurol. 2012, 8, 624-634. [CrossRef]

20. Laveti, D.; Kumar, M.; Hemalatha, R.; Sistla, R.; Naidu, V.G.; Talla, V.; Verma, V.; Kaur, N.; Nagpal, R. Anti-inflammatory treatments for chronic diseases: A review. Inflamm. Allergy Drug Targets 2013, 12, 349-361. [CrossRef]

21. Liu, Q.; Whiteaker, P.; Morley, B.J.; Shi, F.-D.; Lukas, R.J. Distinctive Roles for $\alpha 7^{*}$ - and $\alpha 9^{*}$-Nicotinic Acetylcholine Receptors in Inflammatory and Autoimmune Responses in the Murine Experimental Autoimmune Encephalomyelitis Model of Multiple Sclerosis. Front. Cell. Neurosci. 2017, 11. [CrossRef] [PubMed] 
22. Strom, T.B.; Deisseroth, A.; Morganroth, J.; Carpenter, C.B.; Merrill, J.P. Alteration of the cytotoxic action of sensitized lymphocytes by cholinergic agents and activators of adenylate cyclase. Proc. Natl. Acad. Sci. USA 1972, 69, 2995-2999. [CrossRef] [PubMed]

23. Middlebrook, A.J.; Martina, C.; Chang, Y.; Lukas, R.J.; DeLuca, D. Effects of nicotine exposure on T cell development in fetal thymus organ culture: Arrest of T cell maturation. J. Immunol. 2002, 169, 2915-2924. [CrossRef]

24. Nouri-Shirazi, M.; Guinet, E. Evidence for the immunosuppressive role of nicotine on human dendritic cell functions. Immunology 2003, 109, 365-373. [CrossRef] [PubMed]

25. Pavlov, V.A.; Wang, H.; Czura, C.J.; Friedman, S.G.; Tracey, K.J. The cholinergic anti-inflammatory pathway: A missing link in neuroimmunomodulation. Mol. Med. 2003, 9, 125-134. [CrossRef] [PubMed]

26. Tracey, K.J. Physiology and immunology of the cholinergic antiinflammatory pathway. J. Clin. Investig. 2007, 117, 289-296. [CrossRef] [PubMed]

27. Shoop, R.D.; Martone, M.E.; Yamada, N.; Ellisman, M.H.; Berg, D.K. Neuronal acetylcholine receptors with alpha7 subunits are concentrated on somatic spines for synaptic signaling in embryonic chick ciliary ganglia. J. Neurosci. 1999, 19, 692-704. [CrossRef]

28. Voitenko, L.P.; Voitenko, S.V.; Skok, M.V.; Purnyn, H.E.; Skok, V.I. Nicotinic acetylcholine receptor subtypes in rat superior cervical ganglion neurons as studied by sequential application of two alpha-subunit-specific antibodies. Neurosci. Lett. 2001, 303, 37-40. [CrossRef]

29. Rau, K.K.; Johnson, R.D.; Cooper, B.Y. Nicotinic AChR in subclassified capsaicin-sensitive and -insensitive nociceptors of the rat DRG. J. Neurophysiol. 2005, 93, 1358-1371. [CrossRef]

30. Genzen, J.R.; Van Cleve, W.; McGehee, D.S. Dorsal root ganglion neurons express multiple nicotinic acetylcholine receptor subtypes. J. Neurophysiol. 2001, 86, 1773-1782. [CrossRef]

31. Patel, H.; McIntire, J.; Ryan, S.; Dunah, A.; Loring, R. Anti-inflammatory effects of astroglial $\alpha 7$ nicotinic acetylcholine receptors are mediated by inhibition of the NF-kB pathway and activation of the Nrf2 pathway. J. Neuroinflammation 2017, 14, 192. [CrossRef] [PubMed]

32. Marrero, M.B.; Bencherif, M. Convergence of alpha 7 nicotinic acetylcholine receptor-activated pathways for anti-apoptosis and anti-inflammation: Central role for JAK2 activation of STAT3 and NF-kappaB. Brain Res. 2009, 1256, 1-7. [CrossRef] [PubMed]

33. Abdel-Magid, A.F. Allosteric modulators: An emerging concept in drug discovery. ACS Med. Chem. Lett. 2015, 6, 104-107. [CrossRef] [PubMed]

34. Amor, S.; Puentes, F.; Baker, D.; van der Valk, P. Inflammation in neurodegenerative diseases. Immunology 2010, 129, 154-169. [CrossRef] [PubMed]

35. Gotti, C.; Clementi, F. Neuronal nicotinic receptors: From structure to pathology. Prog. Neurobiol. 2004, 74, 363-396. [CrossRef] [PubMed]

36. Hogg, R.C.; Raggenbass, M.; Bertrand, D. Nicotinic acetylcholine receptors: From structure to brain function. Rev. Physiol. Biochem. Pharmacol. 2003, 147, 1-46. [CrossRef] [PubMed]

37. Corringer, P.J.; Le Novère, N.; Changeux, J.P. Nicotinic receptors at the amino acid level. Annu. Rev. Pharmacol. Toxicol. 2000, 40, 431-458. [CrossRef]

38. Albuquerque, E.X.; Pereira, E.F.R.; Alkondon, M.; Rogers, S.W. Mammalian nicotinic acetylcholine receptors: From structure to function. Physiol. Rev. 2009, 89, 73-120. [CrossRef]

39. Weltzin, M.M.; Huang, Y.; Schulte, M.K. Allosteric modulation of alpha4beta2 nicotinic acetylcholine receptors by HEPES. Eur. J. Pharmacol. 2014, 732, 159-168. [CrossRef]

40. Zwart, R.; Vijverberg, H.P. Four pharmacologically distinct subtypes of alpha4beta2 nicotinic acetylcholine receptor expressed in Xenopus laevis oocytes. Mol. Pharmacol. 1998, 54, 1124-1131. [CrossRef]

41. McGranahan, T.M.; Patzlaff, N.E.; Grady, S.R.; Heinemann, S.F.; Booker, T.K. $\alpha 4 \beta 2$ Nicotinic Acetylcholine Receptors on Dopaminergic Neurons Mediate Nicotine Reward and Anxiety Relief. J. Neurosci. 2011, 31, 10891-10902. [CrossRef]

42. Hone, A.J.; McIntosh, J.M. Nicotinic acetylcholine receptors in neuropathic and inflammatory pain. FEBS Lett. 2018, 592, 1045-1062. [CrossRef] [PubMed]

43. Posadas, I.; López-Hernández, B.; Ceña, V. Nicotinic receptors in neurodegeneration. Curr. Neuropharmacol. 2013, 11, 298-314. [CrossRef] [PubMed]

44. Changeux, J.-P. The nicotinic acetylcholine receptor: A typical 'allosteric machine'. Philos. Trans. R. Soc. Lond. B Biol. Sci. 2018, 373, 20170174. [CrossRef] [PubMed] 
45. Lentz, T.L. Rabies virus binding to an acetylcholine receptor alpha-subunit peptide. J. Mol. Recognit. 1990, 3 , 82-88. [CrossRef] [PubMed]

46. Hueffer, K.; Khatri, S.; Rideout, S.; Harris, M.B.; Papke, R.L.; Stokes, C.; Schulte, M.K. Rabies virus modifies host behaviour through a snake-toxin like region of its glycoprotein that inhibits neurotransmitter receptors in the CNS. Sci. Rep. 2017, 7, 12818. [CrossRef] [PubMed]

47. Williams, D.K.; Wang, J.; Papke, R.L. Positive allosteric modulators as an approach to nicotinic acetylcholine receptor-targeted therapeutics: Advantages and limitations. Biochem. Pharmacol. 2011, 82, 915-930. [CrossRef]

48. Zoli, M.; Pucci, S.; Vilella, A.; Gotti, C. Neuronal and Extraneuronal Nicotinic Acetylcholine Receptors. Curr. Neuropharmacol. 2018, 16, 338-349. [CrossRef] [PubMed]

49. Mohamed, T.S.; Jayakar, S.S.; Hamouda, A.K. Orthosteric and Allosteric Ligands of Nicotinic Acetylcholine Receptors for Smoking Cessation. Front. Mol. Neurosci. 2015, 8, 71. [CrossRef]

50. Luttmann, E.; Ludwig, J.; Höffle-Maas, A.; Samochocki, M.; Maelicke, A.; Fels, G. Structural model for the binding sites of allosterically potentiating ligands on nicotinic acetylcholine receptors. ChemMedChem 2009, 4, 1874-1882. [CrossRef]

51. Taly, A.; Corringer, P.-J.; Guedin, D.; Lestage, P.; Changeux, J.-P. Nicotinic receptors: Allosteric transitions and therapeutic targets in the nervous system. Nat. Rev. Drug Discov. 2009, 8, 733-750. [CrossRef] [PubMed]

52. Sala, F.; Mulet, J.; Reddy, K.P.; Bernal, J.A.; Wikman, P.; Valor, L.M.; Peters, L.; König, G.M.; Criado, M.; Sala, S. Potentiation of human alpha4beta2 neuronal nicotinic receptors by a Flustra foliacea metabolite. Neurosci. Lett. 2005, 373, 144-149. [CrossRef] [PubMed]

53. Springer, S.K.; Woodin, K.S.; Berry, V.; Boezio, A.A.; Cao, L.; Clarkin, K.; Harmange, J.C.; Hierl, M.; Knop, J.; Malmberg, A.B.; et al. Synthesis and activity of substituted carbamates as potentiators of the alpha4beta2 nicotinic acetylcholine receptor. Bioorg. Med. Chem. Lett. 2008, 18, 5643-5647. [CrossRef] [PubMed]

54. Albrecht, B.K.; Berry, V.; Boezio, A.A.; Cao, L.; Clarkin, K.; Guo, W.; Harmange, J.C.; Hierl, M.; Huang, L.; Janosky, B.; et al. Discovery and optimization of substituted piperidines as potent, selective, CNS-penetrant alpha4beta2 nicotinic acetylcholine receptor potentiators. Bioorg. Med. Chem. Lett. 2008, 18, 5209-5212. [CrossRef] [PubMed]

55. Timmermann, D.B.; Sandager-Nielsen, K.; Dyhring, T.; Smith, M.; Jacobsen, A.M.; Nielsen, E.; Grunnet, M.; Christensen, J.K.; Peters, D.; Kohlhaas, K.; et al. Augmentation of cognitive function by NS9283, a stoichiometry-dependent positive allosteric modulator of $\alpha 2$ - and $\alpha 4$-containing nicotinic acetylcholine receptors. Br. J. Pharmacol. 2012, 167, 164-182. [CrossRef] [PubMed]

56. Olsen, J.A.; Ahring, P.K.; Kastrup, J.S.; Gajhede, M.; Balle, T. Structural and functional studies of the modulator NS9283 reveal agonist-like mechanism of action at $\alpha 4 \beta 2$ nicotinic acetylcholine receptors. J. Biol. Chem. 2014, 289, 24911-24921. [CrossRef]

57. Uteshev, V.V. The therapeutic promise of positive allosteric modulation of nicotinic receptors. Eur. J. Pharmacol. 2014, 727, 181-185. [CrossRef] [PubMed]

58. Grønlien, J.H.; Håkerud, M.; Ween, H.; Thorin-Hagene, K.; Briggs, C.A.; Gopalakrishnan, M.; Malysz, J. Distinct profiles of alpha7 $\mathrm{nAChR}$ positive allosteric modulation revealed by structurally diverse chemotypes. Mol. Pharmacol. 2007, 72, 715-724. [CrossRef]

59. Thomsen, M.S.; Mikkelsen, J.D. Type I and II positive allosteric modulators differentially modulate agonist-induced up-regulation of $\alpha 7$ nicotinic acetylcholine receptors. J. Neurochem. 2012, 123, 73-83. [CrossRef]

60. Foster, D.J.; Conn, P.J. Allosteric Modulation of GPCRs: New Insights and Potential Utility for Treatment of Schizophrenia and Other CNS Disorders. Neuron 2017, 94, 431-446. [CrossRef]

61. Chatzidaki, A.; Millar, N.S. Allosteric modulation of nicotinic acetylcholine receptors. Biochem. Pharmacol. 2015, 97, 408-417. [CrossRef] [PubMed]

62. Chang, Y.; Huang, Y.; Whiteaker, P. Mechanism of Allosteric Modulation of the Cys-loop Receptors. Pharmaceuticals 2010, 3, 2592-2609. [CrossRef] [PubMed]

63. Changeux, J.P.; Christopoulos, A. Allosteric Modulation as a Unifying Mechanism for Receptor Function and Regulation. Cell 2016, 166, 1084-1102. [CrossRef] [PubMed]

64. Glass, C.K.; Saijo, K.; Winner, B.; Marchetto, M.C.; Gage, F.H. Mechanisms underlying inflammation in neurodegeneration. Cell 2010, 140, 918-934. [CrossRef] [PubMed]

65. Streit, W.J. Microglia as neuroprotective, immunocompetent cells of the CNS. Glia 2002, 40, 133-139. [CrossRef] [PubMed] 
66. Rahal, A.; Kumar, A.; Singh, V.; Yadav, B.; Tiwari, R.; Chakraborty, S.; Dhama, K. Oxidative stress, prooxidants, and antioxidants: The interplay. Biomed. Res. Int. 2014, 2014, 761264. [CrossRef]

67. Aguilera, G.; Colín-González, A.L.; Rangel-López, E.; Chavarría, A.; Santamaría, A. Redox Signaling, Neuroinflammation, and Neurodegeneration. Antioxid. Redox Signal. 2017, 28, 1626-1651. [CrossRef] [PubMed]

68. Bondi, M.W.; Edmonds, E.C.; Salmon, D.P. Alzheimer's Disease: Past, Present, and Future. J. Int. Neuropsychol. Soc. 2017, 23, 818-831. [CrossRef]

69. Hensley, K.; Maidt, M.L.; Yu, Z.; Sang, H.; Markesbery, W.R.; Floyd, R.A. Electrochemical analysis of protein nitrotyrosine and dityrosine in the Alzheimer brain indicates region-specific accumulation. J. Neurosci. 1998, 18, 8126-8132. [CrossRef]

70. Weller, J.; Budson, A. Current understanding of Alzheimer's disease diagnosis and treatment. F1000Research 2018, 7. [CrossRef]

71. Gomez-Nicola, D.; Boche, D. Post-mortem analysis of neuroinflammatory changes in human Alzheimer's disease. Alzheimers Res. Ther. 2015, 7, 42. [CrossRef] [PubMed]

72. Hopperton, K.E.; Mohammad, D.; Trépanier, M.O.; Giuliano, V.; Bazinet, R.P. Markers of microglia in post-mortem brain samples from patients with Alzheimer's disease: A systematic review. Mol. Psychiatry 2018, 23, 177-198. [CrossRef] [PubMed]

73. Mrak, R.E.; Griffin, W.S. Potential inflammatory biomarkers in Alzheimer's disease. J. Alzheimers Dis. 2005, 8, 369-375. [CrossRef] [PubMed]

74. Mrak, R.E.; Sheng, J.G.; Griffin, W.S. Glial cytokines in Alzheimer's disease: Review and pathogenic implications. Hum. Pathol. 1995, 26, 816-823. [CrossRef]

75. Griffin, W.S.; Stanley, L.C.; Ling, C.; White, L.; MacLeod, V.; Perrot, L.J.; White, C.L., 3rd; Araoz, C. Brain interleukin 1 and S-100 immunoreactivity are elevated in Down syndrome and Alzheimer disease. Proc. Natl. Acad. Sci. USA 1989, 86, 7611-7615. [CrossRef] [PubMed]

76. Rogers, J.; Luber-Narod, J.; Styren, S.D.; Civin, W.H. Expression of immune system-associated antigens by cells of the human central nervous system: Relationship to the pathology of Alzheimer's disease. Neurobiol. Aging 1988, 9, 339-349. [CrossRef]

77. McGeer, P.L.; Schulzer, M.; McGeer, E.G. Arthritis and anti-inflammatory agents as possible protective factors for Alzheimer's disease: A review of 17 epidemiologic studies. Neurology 1996, 47, 425-432. [CrossRef]

78. Luterman, J.D.; Haroutunian, V.; Yemul, S.; Ho, L.; Purohit, D.; Aisen, P.S.; Mohs, R.; Pasinetti, G.M. Cytokine gene expression as a function of the clinical progression of Alzheimer disease dementia. Arch. Neurol. 2000, 57, 1153-1160. [CrossRef]

79. Van der Wal, E.A.; Gómez-Pinilla, F.; Cotman, C.W. Transforming growth factor-beta 1 is in plaques in Alzheimer and Down pathologies. Neuroreport 1993, 4, 69-72. [CrossRef]

80. Rogers, J.; Cooper, N.R.; Webster, S.; Schultz, J.; McGeer, P.L.; Styren, S.D.; Civin, W.H.; Brachova, L.; Bradt, B.; Ward, P.; et al. Complement activation by beta-amyloid in Alzheimer disease. Proc. Natl. Acad. Sci. USA 1992, 89, 10016-10020. [CrossRef]

81. Wood, J.A.; Wood, P.L.; Ryan, R.; Graff-Radford, N.R.; Pilapil, C.; Robitaille, Y.; Quirion, R. Cytokine indices in Alzheimer's temporal cortex: No changes in mature IL-1 $\beta$ or IL-1RA but increases in the associated acute phase proteins IL-6, $\alpha 2$-macroglobulin and C-reactive protein. Brain Res. 1993, 629, 245-252. [CrossRef]

82. Du Yan, S.; Fu, J.; Soto, C.; Chen, X.; Zhu, H.; Al-Mohanna, F.; Collison, K.; Zhu, A.; Stern, E.; Saido, T.; et al. An intracellular protein that binds amyloid- $\beta$ peptide and mediates neurotoxicity in Alzheimer's disease. Nature 1997, 389, 689-695. [CrossRef] [PubMed]

83. Reich, E.E.; Markesbery, W.R.; Roberts, L.J., 2nd; Swift, L.L.; Morrow, J.D.; Montine, T.J. Brain regional quantification of F-ring and D-/E-ring isoprostanes and neuroprostanes in Alzheimer's disease. Am. J. Pathol. 2001, 158, 293-297. [CrossRef]

84. Aksenov, M.Y.; Aksenova, M.V.; Butterfield, D.A.; Geddes, J.W.; Markesbery, W.R. Protein oxidation in the brain in Alzheimer's disease. Neuroscience 2001, 103, 373-383. [CrossRef]

85. Williamson, K.S.; Gabbita, S.P.; Mou, S.; West, M.; Pye, Q.N.; Markesbery, W.R.; Cooney, R.V.; Grammas, P.; Reimann-Philipp, U.; Floyd, R.A.; et al. The nitration product 5-nitro-gamma-tocopherol is increased in the Alzheimer brain. Nitric Oxide 2002, 6, 221-227. [CrossRef]

86. Fakhoury, M. Microglia and Astrocytes in Alzheimer's Disease: Implications for Therapy. Curr. Neuropharmacol. 2018, 16, 508-518. [CrossRef] 
87. Su, F.; Bai, F.; Zhang, Z. Inflammatory Cytokines and Alzheimer's Disease: A Review from the Perspective of Genetic Polymorphisms. Neurosci. Bull. 2016, 32, 469-480. [CrossRef]

88. Auld, D.S.; Kornecook, T.J.; Bastianetto, S.; Quirion, R. Alzheimer's disease and the basal forebrain cholinergic system: Relations to beta-amyloid peptides, cognition, and treatment strategies. Prog. Neurobiol. 2002, 68, 209-245. [CrossRef]

89. Mufson, E.J.; Ginsberg, S.D.; Ikonomovic, M.D.; DeKosky, S.T. Human cholinergic basal forebrain: Chemoanatomy and neurologic dysfunction. J. Chem. Neuroanat. 2003, 26, 233-242. [CrossRef]

90. Mehta, M.; Adem, A.; Sabbagh, M. New acetylcholinesterase inhibitors for Alzheimer's disease. Int. J. Alzheimers Dis. 2012, 2012, 728983. [CrossRef]

91. Skok, M.; Lykhmus, O. The Role of $\alpha 7$ Nicotinic Acetylcholine Receptors and $\alpha 7-$ Specific Antibodies in Neuroinflammation Related to Alzheimer Disease. Curr. Pharm. Des. 2016, 22, 2035-2049. [CrossRef] [PubMed]

92. Mufson, E.J.; Counts, S.E.; Perez, S.E.; Ginsberg, S.D. Cholinergic system during the progression of Alzheimer's disease: Therapeutic implications. Expert Rev. Neurother. 2008, 8, 1703-1718. [CrossRef] [PubMed]

93. Schliebs, R.; Arendt, T. The cholinergic system in aging and neuronal degeneration. Behav. Brain Res. 2011, 221, 555-563. [CrossRef] [PubMed]

94. Cattaneo, A.; Calissano, P. Nerve growth factor and Alzheimer's disease: New facts for an old hypothesis. Mol. Neurobiol. 2012, 46, 588-604. [CrossRef] [PubMed]

95. Triaca, V.; Calissano, P. Impairment of the nerve growth factor pathway driving amyloid accumulation in cholinergic neurons: The incipit of the Alzheimer's disease story? Neural Regen. Res. 2016, 11, 1553-1556. [CrossRef]

96. Turnbull, M.T.; Boskovic, Z.; Coulson, E.J. Acute Down-regulation of BDNF Signaling Does Not Replicate Exacerbated Amyloid- $\beta$ Levels and Cognitive Impairment Induced by Cholinergic Basal Forebrain Lesion. Front. Mol. Neurosci. 2018, 11, 51. [CrossRef]

97. Cuello, A.C.; Bruno, M.A.; Bell, K.F. NGF-cholinergic dependency in brain aging, MCI and Alzheimer's disease. Curr. Alzheimer Res. 2007, 4, 351-358. [CrossRef]

98. Iulita, M.F.; Cuello, A.C. Nerve growth factor metabolic dysfunction in Alzheimer's disease and Down syndrome. Trends Pharmacol. Sci. 2014, 35, 338-348. [CrossRef]

99. Iulita, M.F.; Bistué Millón, M.B.; Pentz, R.; Aguilar, L.F.; Do Carmo, S.; Allard, S.; Michalski, B.; Wilson, E.N.; Ducatenzeiler, A.; Bruno, M.A.; et al. Differential deregulation of NGF and BDNF neurotrophins in a transgenic rat model of Alzheimer's disease. Neurobiol. Dis. 2017, 108, 307-323. [CrossRef]

100. Hampel, H.; Mesulam, M.M.; Cuello, A.C.; Farlow, M.R.; Giacobini, E.; Grossberg, G.T.; Khachaturian, A.S.; Vergallo, A.; Cavedo, E.; Snyder, P.J.; et al. The cholinergic system in the pathophysiology and treatment of Alzheimer's disease. Brain 2018, 141, 1917-1933. [CrossRef]

101. Minnone, G.; De Benedetti, F.; Bracci-Laudiero, L. NGF and Its Receptors in the Regulation of Inflammatory Response. Int. J. Mol. Sci. 2017, 18, 1028. [CrossRef] [PubMed]

102. Warpman, U.; Nordberg, A. Epibatidine and ABT 418 reveal selective losses of $\alpha 4 \beta 2$ nicotinic receptors in Alzheimer brains. Neuroreport 1995, 6, 2419-2423. [CrossRef] [PubMed]

103. Marutle, A.; Warpman, U.; Bogdanovic, N.; Lannfelt, L.; Nordberg, A. Neuronal nicotinic receptor deficits in Alzheimer patients with the Swedish amyloid precursor protein 670/671 mutation. J. Neurochem. 1999, 72, 1161-1169. [CrossRef] [PubMed]

104. Guan, Z.-Z.; Zhang, X.; Ravid, R.; Nordberg, A. Decreased Protein Levels of Nicotinic Receptor Subunits in the Hippocampus and Temporal Cortex of Patients with Alzheimer's Disease. J. Neurochem. 2000, 74, 237-243. [CrossRef]

105. Burghaus, L.; Schütz, U.; Krempel, U.; de Vos, R.A.; Jansen Steur, E.N.; Wevers, A.; Lindstrom, J.; Schröder, H. Quantitative assessment of nicotinic acetylcholine receptor proteins in the cerebral cortex of Alzheimer patients. Brain Res. Mol. Brain Res. 2000, 76, 385-388. [CrossRef]

106. Wevers, A.; Burghaus, L.; Moser, N.; Witter, B.; Steinlein, O.K.; Schütz, U.; Achnitz, B.; Krempel, U.; Nowacki, S.; Pilz, K.; et al. Expression of nicotinic acetylcholine receptors in Alzheimer's disease: Postmortem investigations and experimental approaches. Behav. Brain Res. 2000, 113, 207-215. [CrossRef]

107. Shaw, S.; Bencherif, M.; Marrero, M.B. Janus kinase 2, an early target of alpha 7 nicotinic acetylcholine receptor-mediated neuroprotection against Abeta-(1-42) amyloid. J. Biol. Chem. 2002, 277, 44920-44924. [CrossRef] 
108. Kihara, T.; Shimohama, S.; Sawada, H.; Kimura, J.; Kume, T.; Kochiyama, H.; Maeda, T.; Akaike, A. Nicotinic receptor stimulation protects neurons against $\beta$-amyloid toxicity. Ann. Neurol. 1997, 42, 159-163. [CrossRef]

109. Medeiros, R.; Castello, N.A.; Cheng, D.; Kitazawa, M.; Baglietto-Vargas, D.; Green, K.N.; Esbenshade, T.A.; Bitner, R.S.; Decker, M.W.; LaFerla, F.M. $\alpha 7$ Nicotinic receptor agonist enhances cognition in aged 3xTg-AD mice with robust plaques and tangles. Am. J. Pathol. 2014, 184, 520-529. [CrossRef]

110. Nordberg, A.; Hellström-Lindahl, E.; Lee, M.; Johnson, M.; Mousavi, M.; Hall, R.; Perry, E.; Bednar, I.; Court, J. Chronic nicotine treatment reduces $\beta$-amyloidosis in the brain of a mouse model of Alzheimer's disease (APPsw). J. Neurochem. 2002, 81, 655-658. [CrossRef]

111. Buckingham, S.D.; Jones, A.K.; Brown, L.A.; Sattelle, D.B. Nicotinic acetylcholine receptor signalling: Roles in Alzheimer's disease and amyloid neuroprotection. Pharmacol. Rev. 2009, 61, 39-61. [CrossRef] [PubMed]

112. De Jonge, W.J.; van der Zanden, E.P.; The, F.O.; Bijlsma, M.F.; van Westerloo, D.J.; Bennink, R.J.; Berthoud, H.R.; Uematsu, S.; Akira, S.; van den Wijngaard, R.M.; et al. Stimulation of the vagus nerve attenuates macrophage activation by activating the Jak2-STAT3 signaling pathway. Nat. Immunol. 2005, 6, 844-851. [CrossRef] [PubMed]

113. Lilja, A.M.; Porras, O.; Storelli, E.; Nordberg, A.; Marutle, A. Functional interactions of fibrillar and oligomeric amyloid- $\beta$ with alpha7 nicotinic receptors in Alzheimer's disease. J. Alzheimers Dis. 2011, 23, 335-347. [CrossRef] [PubMed]

114. Oz, M.; Lorke, D.E.; Yang, K.H.; Petroianu, G. On the interaction of $\beta$-amyloid peptides and $\alpha 7$-nicotinic acetylcholine receptors in Alzheimer's disease. Curr. Alzheimer Res. 2013, 10, 618-630. [CrossRef]

115. Lasala, M.; Fabiani, C.; Corradi, J.; Antollini, S.; Bouzat, C. Molecular Modulation of Human $\alpha 7$ Nicotinic Receptor by Amyloid- $\beta$ Peptides. Front. Cell. Neurosci. 2019, 13. [CrossRef]

116. Beitz, J.M. Parkinson's disease: A review. Front. Biosci. (Sch. Ed.) 2014, 6, 65-74. [CrossRef]

117. Spillantini, M.G.; Schmidt, M.L.; Lee, V.M.Y.; Trojanowski, J.Q.; Jakes, R.; Goedert, M. $\alpha$-Synuclein in Lewy bodies. Nature 1997, 388, 839-840. [CrossRef]

118. Dickson, D.W. Parkinson's disease and parkinsonism: Neuropathology. Cold Spring Harb. Perspect. Med. 2012, 2. [CrossRef]

119. Michel, P.P.; Toulorge, D.; Guerreiro, S.; Hirsch, E.C. Specific needs of dopamine neurons for stimulation in order to survive: Implication for Parkinson disease. FASEB J. 2013, 27, 3414-3423. [CrossRef]

120. Jankovic, J. Parkinson's disease: Clinical features and diagnosis. J. Neurol. Neurosurg. Psychiatry 2008, 79, 368-376. [CrossRef]

121. Dubois, B.; Pillon, B. Cognitive deficits in Parkinson's disease. J. Neurol. 1996, 244, 2-8. [CrossRef] [PubMed]

122. Gatto, N.M.; Rhodes, S.L.; Manthripragada, A.D.; Bronstein, J.; Cockburn, M.; Farrer, M.; Ritz, B. $\alpha$-Synuclein Gene May Interact with Environmental Factors in Increasing Risk of Parkinson's Disease. Neuroepidemiology 2010, 35, 191-195. [CrossRef] [PubMed]

123. Warner, T.T.; Schapira, A.H. Genetic and environmental factors in the cause of Parkinson's disease. Ann. Neurol. 2003, 53, 16-23. [CrossRef] [PubMed]

124. Goldman, S.M.; Quinlan, P.J.; Ross, G.W.; Marras, C.; Meng, C.; Bhudhikanok, G.S.; Comyns, K.; Korell, M.; Chade, A.R.; Kasten, M.; et al. Solvent exposures and parkinson disease risk in twins. Ann. Neurol. 2012, 71, 776-784. [CrossRef] [PubMed]

125. Maulik, M.; Mitra, S.; Bult-Ito, A.; Taylor, B.E.; Vayndorf, E.M. Behavioral Phenotyping and Pathological Indicators of Parkinson's Disease in C. elegans Models. Front. Genet. 2017, 8, 77. [CrossRef]

126. Quik, M.; Bordia, T.; Huang, L.; Perez, X. Targeting nicotinic receptors for Parkinson's disease therapy. CNS Neurol. Disord. Drug Targets 2011, 10, 651-658. [CrossRef]

127. Quik, M.; O’Neill, M.; Perez, X. Nicotine neuroprotection against nigrostriatal damage: Importance of the animal model. Trends Pharmacol. Sci. 2007, 28, 229-235. [CrossRef]

128. Quik, M.; O'Leary, K.; Tanner, C.M. Nicotine and Parkinson's disease: Implications for therapy. Mov. Disord. 2008, 23, 1641-1652. [CrossRef]

129. Lu, J.Y.D.; Su, P.; Barber, J.E.M.; Nash, J.E.; Le, A.D.; Liu, F.; Wong, A.H.C. The neuroprotective effect of nicotine in Parkinson's disease models is associated with inhibiting PARP-1 and caspase-3 cleavage. PeerJ 2017, 5, 3933. [CrossRef]

130. Costa, G.; Abin-Carriquiry, J.A.; Dajas, F. Nicotine prevents striatal dopamine loss produced by 6-hydroxydopamine lesion in the substantia nigra. Brain Res. 2001, 888, 336-342. [CrossRef] 
131. Parain, K.; Hapdey, C.; Rousselet, E.; Marchand, V.; Dumery, B.; Hirsch, E.C. Cigarette smoke and nicotine protect dopaminergic neurons against the 1-methyl-4-phenyl-1,2,3,6-tetrahydropyridine Parkinsonian toxin. Brain Res. 2003, 984, 224-232. [CrossRef]

132. Bordia, T.; McGregor, M.; Papke, R.L.; Decker, M.W.; McIntosh, J.M.; Quik, M. The $\alpha 7$ nicotinic receptor agonist ABT-107 protects against nigrostriatal damage in rats with unilateral 6-hydroxydopamine lesions. Exp. Neurol. 2015, 263, 277-284. [CrossRef] [PubMed]

133. Quik, M.; Campos, C.; Bordia, T.; Strachan, J.-P.; Zhang, J.; McIntosh, J.M.; Letchworth, S.; Jordan, K. $\alpha 4 \beta 2$ Nicotinic receptors play a role in the nAChR-mediated decline in L-dopa-induced dyskinesias in parkinsonian rats. Neuropharmacology 2013, 71, 191-203. [CrossRef] [PubMed]

134. Quik, M.; Chen, L.; Parameswaran, N.; Xie, X.; Langston, J.W.; McCallum, S.E. Chronic Oral Nicotine Normalizes Dopaminergic Function and Synaptic Plasticity in 1-Methyl-4-Phenyl-1,2,3,6Tetrahydropyridine-Lesioned Primates. J. Neurosci. 2006, 26, 4681. [CrossRef] [PubMed]

135. Wang, Q.; Liu, Y.; Zhou, J. Neuroinflammation in Parkinson's disease and its potential as therapeutic target. Transl. Neurodegener. 2015, 4, 19. [CrossRef] [PubMed]

136. Kulak, J.M.; McIntosh, J.M.; Quik, M. Loss of nicotinic receptors in monkey striatum after 1-methyl-4-phenyl-1,2,3,6-tetrahydropyridine treatment is due to a decline in alpha-conotoxin MII sites. Mol. Pharmacol. 2002, 61, 230-238. [CrossRef] [PubMed]

137. Quik, M.; Sum, J.D.; Whiteaker, P.; McCallum, S.E.; Marks, M.J.; Musachio, J.; McIntosh, J.M.; Collins, A.C.; Grady, S.R. Differential declines in striatal nicotinic receptor subtype function after nigrostriatal damage in mice. Mol. Pharmacol. 2003, 63, 1169-1179. [CrossRef]

138. Mogi, M.; Harada, M.; Kondo, T.; Riederer, P.; Inagaki, H.; Minami, M.; Nagatsu, T. Interleukin-1 $\beta$, interleukin-6, epidermal growth factor and transforming growth factor- $\alpha$ are elevated in the brain from parkinsonian patients. Neurosci. Lett. 1994, 180, 147-150. [CrossRef]

139. Mogi, M.; Harada, M.; Kondo, T.; Riederer, P.; Nagatsu, T. Brain $\beta 2$-microglobulin levels are elevated in the striatum in Parkinson's diseaselevels are elevated in the striatum in Parkinson's disease. J. Neural Transm. Park. Dis. Dement. Sect. 1995, 9, 87-92. [CrossRef]

140. Blum-Degena, D.; Müller, T.; Kuhn, W.; Gerlach, M.; Przuntek, H.; Riederer, P. Interleukin-1ß and interleukin-6 are elevated in the cerebrospinal fluid of Alzheimer's and de novo Parkinson's disease patients. Neurosci. Lett. 1995, 202, 17-20. [CrossRef]

141. Mount, M.P.; Lira, A.; Grimes, D.; Smith, P.D.; Faucher, S.; Slack, R.; Anisman, H.; Hayley, S.; Park, D.S. Involvement of interferon-gamma in microglial-mediated loss of dopaminergic neurons. J. Neurosci. 2007, 27, 3328-3337. [CrossRef] [PubMed]

142. Chao, Y.; Wong, S.C.; Tan, E.K. Evidence of inflammatory system involvement in Parkinson's disease. Biomed. Res. Int. 2014, 2014, 308654. [CrossRef] [PubMed]

143. Visanji, N.P.; O'Neill, M.J.; Duty, S. Nicotine, but neither the $\alpha 4 \beta 2$ ligand RJR2403 nor an $\alpha 7$ nAChR subtype selective agonist, protects against a partial 6-hydroxydopamine lesion of the rat median forebrain bundle. Neuropharmacology 2006, 51, 506-516. [CrossRef] [PubMed]

144. Ryan, R.E.; Ross, S.A.; Drago, J.; Loiacono, R.E. Dose-related neuroprotective effects of chronic nicotine in 6-hydroxydopamine treated rats, and loss of neuroprotection in alpha4 nicotinic receptor subunit knockout mice. Br. J. Pharmacol. 2001, 132, 1650-1656. [CrossRef] [PubMed]

145. Exley, R.; McIntosh, J.M.; Marks, M.J.; Maskos, U.; Cragg, S.J. Striatal $\alpha 5$ nicotinic receptor subunit regulates dopamine transmission in dorsal striatum. J. Neurosci. 2012, 32, 2352-2356. [CrossRef] [PubMed]

146. Exley, R.; Maubourguet, N.; David, V.; Eddine, R.; Evrard, A.; Pons, S.; Marti, F.; Threlfell, S.; Cazala, P.; McIntosh, J.M.; et al. Distinct contributions of nicotinic acetylcholine receptor subunit $\alpha 4$ and subunit $\alpha 6$ to the reinforcing effects of nicotine. Proc. Natl. Acad. Sci. USA 2011, 108, 7577-7582. [CrossRef]

147. Shen, J.-x.; Yakel, J.L. Nicotinic acetylcholine receptor-mediated calcium signaling in the nervous system. Acta Pharmacol. Sin. 2009, 30, 673-680. [CrossRef]

148. Kawamata, J.; Suzuki, S.; Shimohama, S. Enhancement of nicotinic receptors alleviates cytotoxicity in neurological disease models. Ther. Adv. Chronic Dis. 2011, 2, 197-208. [CrossRef] [PubMed]

149. Li, Y.; Hai, S.; Zhou, Y.; Dong, B.R. Cholinesterase inhibitors for rarer dementias associated with neurological conditions. Cochrane Database Syst. Rev. 2015, 3, Cd009444. [CrossRef] [PubMed] 
150. Petiet, A.; Aigrot, M.-S.; Stankoff, B. Gray and White Matter Demyelination and Remyelination Detected with Multimodal Quantitative MRI Analysis at 11.7T in a Chronic Mouse Model of Multiple Sclerosis. Front. Neurosci. 2016, 10, 491. [CrossRef]

151. Aktas, O.; Waiczies, S.; Zipp, F. Neurodegeneration in autoimmune demyelination: Recent mechanistic insights reveal novel therapeutic targets. J. Neuroimmunol. 2007, 184, 17-26. [CrossRef] [PubMed]

152. Bazan, N.; Halabi, A.; Ertel, M.; Petasis, N. Neuroinflammation. In Basic Neurochemistry: Molecular, Cellular, and Medical Aspects, 8th ed.; Brady, S., Siegel, G., Albers, R.W., Price, D., Eds.; Elsevier: New York, NY, USA, 2012; pp. 610-620.

153. Bjelobaba, I.; Savic, D.; Lavrnja, I. Multiple Sclerosis and Neuroinflammation: The Overview of Current and Prospective Therapies. Curr. Pharm. Des. 2017, 23, 693-730. [CrossRef] [PubMed]

154. Hemmer, B.; Kerschensteiner, M.; Korn, T. Role of the innate and adaptive immune responses in the course of multiple sclerosis. Lancet. Neurol. 2015, 14, 406-419. [CrossRef]

155. Darvesh, S.; Leblanc, A.M.; Macdonald, I.R.; Reid, G.A.; Bhan, V.; Macaulay, R.J.; Fisk, J.D. Butyrylcholinesterase activity in multiple sclerosis neuropathology. Chem. Biol. Interact. 2010, 187, 425-431. [CrossRef] [PubMed]

156. Dash, P.K.; Zhao, J.; Kobori, N.; Redell, J.B.; Hylin, M.J.; Hood, K.N.; Moore, A.N. Activation of Alpha 7 Cholinergic Nicotinic Receptors Reduce Blood-Brain Barrier Permeability following Experimental Traumatic Brain Injury. J. Neurosci. 2016, 36, 2809-2818. [CrossRef]

157. Anglister, L.; Etlin, A.; Finkel, E.; Durrant, A.R.; Lev-Tov, A. Cholinesterases in development and disease. Chem. Biol. Interact. 2008, 175, 92-100. [CrossRef]

158. Gao, Z.; Nissen, J.C.; Ji, K.; Tsirka, S.E. The experimental autoimmune encephalomyelitis disease course is modulated by nicotine and other cigarette smoke components. PLoS ONE 2014, 9, e107979. [CrossRef]

159. Nizri, E.; Irony-Tur-Sinai, M.; Lory, O.; Orr-Urtreger, A.; Lavi, E.; Brenner, T. Activation of the cholinergic anti-inflammatory system by nicotine attenuates neuroinflammation via suppression of Th1 and Th17 responses. J. Immunol. 2009, 183, 6681-6688. [CrossRef]

160. Fujii, T.; Mashimo, M.; Moriwaki, Y.; Misawa, H.; Ono, S.; Horiguchi, K.; Kawashima, K. Physiological functions of the cholinergic system in immune cells. J. Pharmacol. Sci. 2017, 134,1-21. [CrossRef]

161. Nicolussi, E.M.; Huck, S.; Lassmann, H.; Bradl, M. The cholinergic anti-inflammatory system limits T cell infiltration into the neurodegenerative CNS, but cannot counteract complex CNS inflammation. Neurobiol. Dis. 2009, 35, 24-31. [CrossRef]

162. Treinin, M.; Papke, R.L.; Nizri, E.; Ben-David, Y.; Mizrachi, T.; Brenner, T. Role of the $\alpha 7$ Nicotinic Acetylcholine Receptor and RIC-3 in the Cholinergic Anti-inflammatory Pathway. Cent. Nerv. Syst. Agents Med. Chem. 2017, 17, 90-99. [CrossRef] [PubMed]

163. Tyagi, E.; Agrawal, R.; Nath, C.; Shukla, R. Inhibitory role of cholinergic system mediated via alpha7 nicotinic acetylcholine receptor in LPS-induced neuro-inflammation. Innate Immun. 2010, 16, 3-13. [CrossRef] [PubMed]

164. Nizri, E.; Hamra-Amitay, Y.; Sicsic, C.; Lavon, I.; Brenner, T. Anti-inflammatory properties of cholinergic up-regulation: A new role for acetylcholinesterase inhibitors. Neuropharmacology 2006, 50, 540-547. [CrossRef]

165. Zabrodskii, P.F. Effect of acetylcholine on mortality of mice from sepsis and proinflammatory cytokine production. Bull. Exp. Biol. Med. 2011, 150, 340-342. [CrossRef] [PubMed]

166. Gross, C.C.; Schulte-Mecklenbeck, A.; Wiendl, H.; Marcenaro, E.; Kerlero de Rosbo, N.; Uccelli, A.; Laroni, A. Regulatory Functions of Natural Killer Cells in Multiple Sclerosis. Front. Immunol. 2016, 7, 606. [CrossRef] [PubMed]

167. Frebel, H.; Nindl, V.; Schuepbach, R.A.; Braunschweiler, T.; Richter, K.; Vogel, J.; Wagner, C.A.; Loffing-Cueni, D.; Kurrer, M.; Ludewig, B.; et al. Programmed death 1 protects from fatal circulatory failure during systemic virus infection of mice. J. Exp. Med. 2012, 209, 2485-2499. [CrossRef] [PubMed]

168. Jiang, W.; Li, D.; Han, R.; Zhang, C.; Jin, W.-N.; Wood, K.; Liu, Q.; Shi, F.-D.; Hao, J. Acetylcholine-producing NK cells attenuate CNS inflammation via modulation of infiltrating monocytes/macrophages. Proc. Natl. Acad. Sci. USA 2017, 114, 6202-6211. [CrossRef] [PubMed]

169. Jørgensen, N.P.; Alstrup, A.K.; Mortensen, F.V.; Knudsen, K.; Jakobsen, S.; Madsen, L.B.; Bender, D.; Breining, P.; Petersen, M.S.; Schleimann, M.H.; et al. Cholinergic PET imaging in infections and inflammation using (11)C-donepezil and (18)F-FEOBV. Eur. J. Nucl. Med. Mol. Imaging 2017, 44, 449-458. [CrossRef] 
170. Nizri, E.; Brenner, T. Modulation of inflammatory pathways by the immune cholinergic system. Amino Acids 2013, 45, 73-85. [CrossRef]

171. Puzanov, I.; Diab, A.; Abdallah, K.; Bingham, C.O.; Brogdon, C.; Dadu, R.; Hamad, L.; Kim, S.; Lacouture, M.E.; LeBoeuf, N.R.; et al. Managing toxicities associated with immune checkpoint inhibitors: Consensus recommendations from the Society for Immunotherapy of Cancer (SITC) Toxicity Management Working Group. J. ImmunoTher. Cancer 2017, 5, 95. [CrossRef]

172. Brudno, J.N.; Kochenderfer, J.N. Toxicities of chimeric antigen receptor T cells: Recognition and management. Blood 2016, 127, 3321-3330. [CrossRef] [PubMed]

173. Galgano, M.; Toshkezi, G.; Qiu, X.; Russell, T.; Chin, L.; Zhao, L.R. Traumatic Brain Injury: Current Treatment Strategies and Future Endeavors. Cell Transplant. 2017, 26, 1118-1130. [CrossRef] [PubMed]

174. Kayani, N.A.; Homan, S.; Yun, S.; Zhu, B.P. Health and economic burden of traumatic brain injury: Missouri, 2001-2005. Public Health Rep. 2009, 124, 551-560. [CrossRef]

175. Shlosberg, D.; Benifla, M.; Kaufer, D.; Friedman, A. Blood-brain barrier breakdown as a therapeutic target in traumatic brain injury. Nat. Rev. Neurol. 2010, 6, 393-403. [CrossRef] [PubMed]

176. Chodobski, A.; Zink, B.J.; Szmydynger-Chodobska, J. Blood-brain barrier pathophysiology in traumatic brain injury. Transl. Stroke Res. 2011, 2, 492-516. [CrossRef] [PubMed]

177. Donat, C.K.; Scott, G.; Gentleman, S.M.; Sastre, M. Microglial Activation in Traumatic Brain Injury. Front. Aging Neurosci. 2017, 9. [CrossRef] [PubMed]

178. Dixon, C.E.; Bao, J.; Bergmann, J.S.; Johnson, K.M. Traumatic brain injury reduces hippocampal high-affinity [3H]choline uptake but not extracellular choline levels in rats. Neurosci. Lett. 1994, 180, 127-130. [CrossRef]

179. Dixon, C.E.; Flinn, P.; Bao, J.; Venya, R.; Hayes, R.L. Nerve growth factor attenuates cholinergic deficits following traumatic brain injury in rats. Exp. Neurol. 1997, 146, 479-490. [CrossRef]

180. Donat, C.K.; Schuhmann, M.U.; Voigt, C.; Nieber, K.; Deuther-Conrad, W.; Brust, P. Time-dependent alterations of cholinergic markers after experimental traumatic brain injury. Brain Res. 2008, 1246, 167-177. [CrossRef]

181. Titus, D.J.; Johnstone, T.; Johnson, N.H.; London, S.H.; Chapalamadugu, M.; Hogenkamp, D.; Gee, K.W.; Atkins, C.M. Positive allosteric modulation of the $\alpha 7$ nicotinic acetylcholine receptor as a treatment for cognitive deficits after traumatic brain injury. PLoS ONE 2019, 14, e0223180. [CrossRef]

182. Shin, S.S.; Dixon, C.E. Alterations in Cholinergic Pathways and Therapeutic Strategies Targeting Cholinergic System after Traumatic Brain Injury. J. Neurotrauma 2015, 32, 1429-1440. [CrossRef] [PubMed]

183. Murdoch, I.; Nicoll, J.A.; Graham, D.I.; Dewar, D. Nucleus basalis of Meynert pathology in the human brain after fatal head injury. J. Neurotrauma 2002, 19, 279-284. [CrossRef] [PubMed]

184. Östberg, A.; Virta, J.; Rinne, J.O.; Oikonen, V.; Luoto, P.; Någren, K.; Arponen, E.; Tenovuo, O. Cholinergic dysfunction after traumatic brain injury: Preliminary findings from a PET study. Neurology 2011, 76, 1046-1050. [CrossRef] [PubMed]

185. Ramlackhansingh, A.F.; Brooks, D.J.; Greenwood, R.J.; Bose, S.K.; Turkheimer, F.E.; Kinnunen, K.M.; Gentleman, S.; Heckemann, R.A.; Gunanayagam, K.; Gelosa, G.; et al. Inflammation after trauma: Microglial activation and traumatic brain injury. Ann. Neurol. 2011, 70, 374-383. [CrossRef] [PubMed]

186. Gatson, J.W.; Simpkins, J.W.; Uteshev, V.V. High therapeutic potential of positive allosteric modulation of $\alpha 7 \mathrm{nAChRs}$ in a rat model of traumatic brain injury: Proof-of-concept. Brain Res. Bull. 2015, 112, 35-41. [CrossRef] [PubMed]

187. Verbois, S.L.; Scheff, S.W.; Pauly, J.R. Time-dependent changes in rat brain cholinergic receptor expression after experimental brain injury. J. Neurotrauma 2002, 19, 1569-1585. [CrossRef]

188. Han, Z.; Li, L.; Wang, L.; Degos, V.; Maze, M.; Su, H. Alpha-7 nicotinic acetylcholine receptor agonist treatment reduces neuroinflammation, oxidative stress, and brain injury in mice with ischemic stroke and bone fracture. J. Neurochem. 2014, 131, 498-508. [CrossRef]

189. Chen, H.; Zhou, X.; Wang, A.; Zheng, Y.; Gao, Y.; Zhou, J. Evolutions in fragment-based drug design: The deconstruction-reconstruction approach. Drug Discov. Today 2015, 20, 105-113. [CrossRef]

190. Lipinski, C.A.; Lombardo, F.; Dominy, B.W.; Feeney, P.J. Experimental and computational approaches to estimate solubility and permeability in drug discovery and development settings. Adv. Drug Deliv. Rev. 1997, 23, 3-25. [CrossRef]

191. Veber, D.F.; Johnson, S.R.; Cheng, H.Y.; Smith, B.R.; Ward, K.W.; Kopple, K.D. Molecular properties that influence the oral bioavailability of drug candidates. J. Med. Chem. 2002, 45, 2615-2623. [CrossRef] 
192. Peters, L.; König, G.M.; Terlau, H.; Wright, A.D. Four new bromotryptamine derivatives from the marine bryozoan Flustra foliacea. J. Nat. Prod. 2002, 65, 1633-1637. [CrossRef] [PubMed]

193. Weltzin, M.M.; Schulte, M.K. Pharmacological characterization of the allosteric modulator desformylflustrabromine and its interaction with alpha4beta2 neuronal nicotinic acetylcholine receptor orthosteric ligands. J. Pharmacol. Exp. Ther. 2010, 334, 917-926. [CrossRef] [PubMed]

194. Kim, J.-S.; Padnya, A.; Weltzin, M.; Edmonds, B.W.; Schulte, M.K.; Glennon, R.A. Synthesis of desformylflustrabromine and its evaluation as an alpha4beta2 and alpha7 nACh receptor modulator. Bioorg. Med. Chem. Lett. 2007, 17, 4855-4860. [CrossRef] [PubMed]

195. Liu, X. Positive allosteric modulation of $\alpha 4 \beta 2$ nicotinic acetylcholine receptors as a new approach to smoking reduction: Evidence from a rat model of nicotine self-administration. Psychopharmacology 2013, 230, $203-213$. [CrossRef] [PubMed]

196. Mitra, S.; Mucha, M.; Khatri, S.N.; Glenon, R.; Schulte, M.K.; Bult-Ito, A. Attenuation of Compulsive-Like Behavior Through Positive Allosteric Modulation of $\alpha 4 \beta 2$ Nicotinic Acetylcholine Receptors in Non-Induced Compulsive-Like Mice. Front. Behav. Neurosci. 2016, 10, 244. [CrossRef] [PubMed]

197. Schulte, M.K.; Glennon, R.A.; Bult-Ito, A.; Khatri, S.; Mitra, S. Compositions and Methods for Treating Compulsive-Like Behavior in a Subject. Google Patent 16/084291, 21 February 2019.

198. Bagdas, D.; Ergun, D.; Jackson, A.; Toma, W.; Schulte, M.K.; Damaj, M.I. Allosteric modulation of alpha4beta2* nicotinic acetylcholine receptors: Desformylflustrabromine potentiates antiallodynic response of nicotine in a mouse model of neuropathic pain. Eur. J. Pain 2018, 22, 84-93. [CrossRef]

199. Saika, F.; Kiguchi, N.; Kobayashi, Y.; Kishioka, S. Peripheral alpha4beta2 nicotinic acetylcholine receptor signalling attenuates tactile allodynia and thermal hyperalgesia after nerve injury in mice. Acta Physiol. 2015, 213, 462-471. [CrossRef]

200. Pandya, A.; Yakel, J.L. Allosteric modulator Desformylflustrabromine relieves the inhibition of $\alpha 2 \beta 2$ and $\alpha 4 \beta 2$ nicotinic acetylcholine receptors by $\beta$-amyloid(1-42) peptide. J. Mol. Neurosci. 2011, 45, $42-47$. [CrossRef]

201. Jin, X.; Bermudez, I.; Steinbach, J.H. The nicotinic $\alpha 5$ subunit can replace either an acetylcholine-binding or nonbinding subunit in the $\alpha 4 \beta 2^{*}$ neuronal nicotinic receptor. Mol. Pharmacol. 2014, 85, 11-17. [CrossRef]

202. Anderson, D.J.; Malysz, J.; Grønlien, J.H.; El Kouhen, R.; Håkerud, M.; Wetterstrand, C.; Briggs, C.A.; Gopalakrishnan, M. Stimulation of dopamine release by nicotinic acetylcholine receptor ligands in rat brain slices correlates with the profile of high, but not low, sensitivity alpha4beta2 subunit combination. Biochem. Pharmacol. 2009, 78, 844-851. [CrossRef]

203. Olsen, J.; Kastrup, J.; Peters, D.; Gajhede, M.; Balle, T.; Ahring, P. Two Distinct Allosteric Binding Sites at $\alpha 4 \beta 2$ Nicotinic Acetylcholine Receptors Revealed by NS206 and NS9283 Give Unique Insights to Binding-Activity Associated Linkage at Cys-Loop Receptors. J. Biol. Chem. 2013, 288. [CrossRef] [PubMed]

204. Moraes-Cerdeira, R.M.; Burandt, C.L., Jr.; Bastos, J.K.; Nanayakkara, D.; Mikell, J.; Thurn, J.; McChesney, J.D. Evaluation of four Narcissus cultivars as potential sources for galanthamine production. Planta Med. 1997, 63, 472-474. [CrossRef] [PubMed]

205. Samochocki, M.; Höffle, A.; Fehrenbacher, A.; Jostock, R.; Ludwig, J.; Christner, C.; Radina, M.; Zerlin, M.; Ullmer, C.; Pereira, E.F.; et al. Galantamine is an allosterically potentiating ligand of neuronal nicotinic but not of muscarinic acetylcholine receptors. J. Pharmacol. Exp. Ther. 2003, 305, 1024-1036. [CrossRef]

206. Pereira, E.F.; Alkondon, M.; Reinhardt, S.; Maelicke, A.; Peng, X.; Lindstrom, J.; Whiting, P.; Albuquerque, E.X. Physostigmine and galanthamine: Probes for a novel binding site on the alpha 4 beta 2 subtype of neuronal nicotinic acetylcholine receptors stably expressed in fibroblast cells. J. Pharmacol. Exp. Ther. 1994, 270, 768-778. [PubMed]

207. Maelicke, A.; Samochocki, M.; Jostock, R.; Fehrenbacher, A.; Ludwig, J.; Albuquerque, E.X.; Zerlin, M. Allosteric sensitization of nicotinic receptors by galantamine, a new treatment strategy for Alzheimer's disease. Biol. Psychiatry 2001, 49, 279-288. [CrossRef]

208. Niederhofer, H.; Staffen, W.; Mair, A. Galantamine may be effective in treating autistic disorder. BMJ 2002, 325, 1422. [CrossRef] [PubMed]

209. Kowal, N.M.; Ahring, P.K.; Liao, V.W.Y.; Indurti, D.C.; Harvey, B.S.; O'Connor, S.M.; Chebib, M.; Olafsdottir, E.S.; Balle, T. Galantamine is not a positive allosteric modulator of human $\alpha 4 \beta 2$ or $\alpha 7$ nicotinic acetylcholine receptors. Br. J. Pharmacol. 2018, 175, 2911-2925. [CrossRef] [PubMed] 
210. Texidó, L.; Ros, E.; Martín-Satué, M.; López, S.; Aleu, J.; Marsal, J.; Solsona, C. Effect of galantamine on the human alpha7 neuronal nicotinic acetylcholine receptor, the Torpedo nicotinic acetylcholine receptor and spontaneous cholinergic synaptic activity. Br. J. Pharmacol. 2005, 145, 672-678. [CrossRef] [PubMed]

211. Wazea, S.A.; Wadie, W.; Bahgat, A.K.; El-Abhar, H.S. Galantamine anti-colitic effect: Role of alpha-7 nicotinic acetylcholine receptor in modulating Jak/STAT3, NF-kB/HMGB1/RAGE and p-AKT/Bcl-2 pathways. Sci. Rep. 2018, 8, 5110. [CrossRef]

212. Godin, J.R.; Roy, P.; Quadri, M.; Bagdas, D.; Toma, W.; Narendrula-Kotha, R.; Kishta, O.A.; Damaj, M.I.; Horenstein, N.A.; Papke, R.L.; et al. A silent agonist of alpha7 nicotinic acetylcholine receptors modulates inflammation ex vivo and attenuates EAE. Brain Behav. Immun. 2020, 87, 286-300. [CrossRef]

213. Triggle, D.J.; Mitchell, J.M.; Filler, R. The Pharmacology of Physostigmine. CNS Drug Rev. 1998, 4, 87-136. [CrossRef]

214. Freitas, K.; Negus, S.S.; Carroll, F.I.; Damaj, M.I. In vivo pharmacological interactions between a type II positive allosteric modulator of $\alpha 7$ nicotinic ACh receptors and nicotinic agonists in a murine tonic pain model. Br. J. Pharmacol. 2013, 169, 567-579. [CrossRef] [PubMed]

215. Freitas, K.; Ghosh, S.; Ivy Carroll, F.; Lichtman, A.H.; Imad Damaj, M. Effects of $\alpha 7$ positive allosteric modulators in murine inflammatory and chronic neuropathic pain models. Neuropharmacology 2013, 65, 156-164. [CrossRef] [PubMed]

216. Freitas, K.; Carroll, F.I.; Damaj, M.I. The antinociceptive effects of nicotinic receptors $\alpha 7$-positive allosteric modulators in murine acute and tonic pain models. J. Pharmacol. Exp. Ther. 2013, 344, 264-275. [CrossRef] [PubMed]

217. Bagdas, D.; Wilkerson, J.L.; Kulkarni, A.; Toma, W.; AlSharari, S.; Gul, Z.; Lichtman, A.H.; Papke, R.L.; Thakur, G.A.; Damaj, M.I. The $\alpha 7$ nicotinic receptor dual allosteric agonist and positive allosteric modulator GAT107 reverses nociception in mouse models of inflammatory and neuropathic pain. Br. J. Pharmacol. 2016, 173, 2506-2520. [CrossRef] [PubMed]

218. Robertson, S.J.; Martin, R.J. Levamisole-activated single-channel currents from muscle of the nematode parasite Ascaris suum. Br. J. Pharmacol. 1993, 108, 170-178. [CrossRef] [PubMed]

219. Robertson, S.J.; Pennington, A.J.; Evans, A.M.; Martin, R.J. The action of pyrantel as an agonist and an open channel blocker at acetylcholine receptors in isolated Ascaris suum muscle vesicles. Eur. J. Pharmacol. 1994, 271, 273-282. [CrossRef]

220. Martin, R.J. Modes of action of anthelmintic drugs. Vet. J. 1997, 154, 11-34. [CrossRef]

221. Macdonald, J.S. Adjuvant therapy of colon cancer. CA Cancer J. Clin. 1999, 49, 202-219. [CrossRef]

222. Gaertner, E.M.; Switlyk, S.A. Dermatologic complications from levamisole-contaminated cocaine: A case report and review of the literature. Cutis 2014, 93, 102-106.

223. Ching, J.A.; Smith, D.J., Jr. Levamisole-induced necrosis of skin, soft tissue, and bone: Case report and review of literature. J. Burn Care Res. 2012, 33, 1-5. [CrossRef] [PubMed]

224. Levandoski, M.M.; Piket, B.; Chang, J. The anthelmintic levamisole is an allosteric modulator of human neuronal nicotinic acetylcholine receptors. Eur. J. Pharmacol. 2003, 471, 9-20. [CrossRef]

225. Emil, N.S.; Cisneros, D.R.; Penmetsa, S.; Duchesne, J.H.; Sibbitt, W.L., Jr.; Gibb, J.I.; Noronha, L.E.; Fangtham, M.; Fields, R.A.; Bankhurst, A.D. Atypical Chronic Inflammatory ANCA-Positive Deforming Arthritis After Cocaine-Levamisole Exposure. J. Clin. Rheumatol. 2020, 26, 24-32. [CrossRef] [PubMed]

(C) 2020 by the authors. Licensee MDPI, Basel, Switzerland. This article is an open access article distributed under the terms and conditions of the Creative Commons Attribution (CC BY) license (http://creativecommons.org/licenses/by/4.0/). 